$3-1-2003$

\title{
Portrayals of Violence and Group Difference in Newspaper Photographs: Nationalism and Media
}

Carolyn Marvin

University of Pennsylvania, cmarvin@asc.upenn.edu

Jessica M. Fishman

Follow this and additional works at: https://repository.upenn.edu/asc_papers

Part of the Communication Commons

\section{Recommended Citation}

Marvin, C., \& Fishman, J. M. (2003). Portrayals of Violence and Group Difference in Newspaper Photographs: Nationalism and Media. Journal of Communication, 53 32-44. https:// doi.org/10.1111/j.1460-2466.2003.tb03003.x

This paper is posted at ScholarlyCommons. https://repository.upenn.edu/asc_papers/649

For more information, please contact repository@pobox.upenn.edu. 


\title{
Portrayals of Violence and Group Difference in Newspaper Photographs: Nationalism and Media
}

\begin{abstract}
The authors analyzed group membership of violent agents and types of violence in front-page photographs from 21 years of The New York Times. Using a trimodal definition of media violence, they confirmed the hypothesis that non-U.S. agents are represented as more explicitly violent than U.S. agents, and that the latter are associated with disguised modes of violence more often than the former. The recurring image of non-U.S. violence is that of order brutally ruptured or enforced. By contrast, images of U.S. violence are less alarming and suggest order without cruelty. The study showed how violent imagery is associated with in-group and outgroup status stratification.
\end{abstract}

\author{
Disciplines \\ Communication | Social and Behavioral Sciences
}


Portrayals of Violence and Group Difference in Newspaper Photographs: Nationalism and Media

By Jessica M. Fishman and Carolyn Marvin

The authors analyzed group membership of violent agents and types of violence in front-page photographs from 21 years of The New York Times. Using a trimodal definition of media violence, they confirmed the hypothesis that non-U.S. agents are represented as more explicitly violent than U.S. agents, and that the latter are associated with disguised modes of violence more often than the former. The recurring image of non-U.S. violence is that of order brutally ruptured or enforced. By contrast, images of U.S. violence are less alarming and suggest order without cruelty. The study showed how violent imagery is associated with in-group and out-group status stratification.

A classic function attributed to mass media is enforcing social norms (Lazarsfeld \& Merton, 1948). The fear that desired norms might be undermined by violent media messages has often crystallized around Hollywood and other lowbrow media fare thought to be heavy on sensation and light on moral analysis. How, though, are violent images presented in the most respectable media to the most respectable classes? What does violence look like on the front page of The New York Times, which former Executive Editor Max Frankel says, "frames the intellectual and emotional agenda of serious Americans" (1999, p. 415)? How do prestige media represent violence in the world?

This study focuses on the construction of U.S. identity from comparative representations of violence by national in-groups (U.S.) and out-groups (nonU.S.). On the basis of a widely shared presumption that violence is typically a negative social act, and that groups that use violence are less morally upright than groups that do not, we offer two hypotheses. The first is that U.S. identity is associated with visual displays of implicit or concealed violence. The second is that non-U.S. identity is associated with displays of explicit violence. Such a pattern suggests that, visually speaking, "we" are the good guys, "they" are not, and the way each side exercises physical force is how we tell the difference.

The logic of our hypothesized pattern is consistent with the claims of social identity theory in which categorization, identity, and comparison are basic to processes such as stereotyping, group evaluation, and social influence (see Tajfel, 
1981; Tajfel \& Turner, 1979). Social identity theorists argue that group members compare their group with others on dimensions that cast a positive light on themselves. Along similar lines, theorists have examined the ideological tendency to create and reproduce photographic codes that mark cultural "others" not only as distinct, but often as bizarre, primitive, sexualized, dehumanized, or otherwise lacking in moral quality (Alloula, 1987; Edwards, 1992; Kirshenblatt-Gimlett, 1998; Lutz \& Collins, 1993; Quartermaine, 1992; Urry, 1990). At the extreme, they may even be represented as ultimate others, the dead (Fishman, 2001, in press).

Herman and Chomsky (1988) have argued that U.S. print media portray persons punished by enemy states as virtuous, and persons punished by our government or its allies as virtueless. This analysis speaks to a tradition that examines the press as a handmaiden of national interests (Briggs, 1985; Hallin, 1994; Jowett, 1993; Walsh, 1995; Wombell, 1986), though few theorists have focused explicitly on the contribution of violent images to in-group and out-group distinctions in news media. Finally, any pattern of findings must also address how objective circumstances rather than group codes may affect the observed patterns of representation.

We chose The New York Times, the preeminent American newspaper, for our study. By reputation it represents the highest professional standards of journalism in the United States and sets the agenda for other U.S. newspapers (Glasser \& Salmon, 1995, p. 291). We sampled front pages of the Times, the editorial face of the newspaper. From an infinite informational world, front-page news carves out familiar group interests and identities in concentrated visual space. Here is where the Times speaks loudest, the most important news of the day appears, and news values and practices are most sharply drawn (Gelsanleiter, 1995; Reisner, 1992). We focus on photographs rather than news stories because visual images are often thought to have powerful effects, and because less attention has been given to newspaper photographs in studies of violent imagery (but see Taylor, 1998).

\section{Method}

Definitions of violence in media studies are generally based on narrow criteria of physical and sometimes verbal coercion. Because we believe visual gradations of violence mark distinctions in the social meanings of violence, we define violence as a range of coercive behaviors, including some that have previously been 
overlooked. We thus expand our definition of violence beyond expressions of immediate, direct physical force to coercion that is less explicitly referenced. We classify as violent not only images of overt physical force but any visual representation of coercive agency, agents, or effects. Agency refers to any objects or facilities-for example, weapons, war materiel, and prisons - that are used to exercise coercion against persons. Agents refers to whoever engages in coercion. Effects refers to visual representations of the physical consequences of violence, whether or not its agents are imaged simultaneously. For example, damage to animate beings or inanimate objects such as bombed buildings depict effects of violence.

We propose to expand the empirical sensitivity of definitions of violence by recognizing three coercive modes. The mode of explicit violence is seriously intended and performed. We define it as the photographic representation of the direct, intentional application of physical force or its effects. Explicit violence is the mode most often examined in studies of television violence (see, for example, the National Television Violence Study).

Images of latent violence do not show the immediate application of direct physical force. Instead, elements of the image or caption tell observers that such force could be applied. Photographs of weapons that are not directly exerting physical force depict latent violence because of their injurious potential. Likewise, even when police and military personnel are not applying force directly, their uniforms signal authority and willingness to exercise coercion against threats to the social order. For instance, photographs of National Guardsmen holding guns that are not being discharged may not conventionally qualify as violent images. Still, they reference the guards' capacity and willingness to exert physical force. Both guns that are shown actively shooting and those that are holstered or pointed at suspects index violence. Latent violence is thus seriously intended, but not performed.

Dramatic violence occurs for diversion or amusement. It is performed, but not seriously intended. It entails the visible exercise of explicit or latent force but brackets it as playful. Though boxers pummel one another furiously, everyone knows they will return to their corners when the bell sounds. They do not "mean" what a soldier "means" when he faces another combatant. Sports violence is not seen as a disruption of the social order. (By contrast, violence outside the rules in fan riots or off-field fights among players counts as explicit rather than dramatic violence.) When Shakespearean protagonists duel, everyone knows the 
combatants do not believe that a serious duel is in the offing. If a film portrays a murder, viewers understand this depiction as symbolic rather than real.

\section{Procedures}

To analyze examples of explicit, latent, and dramatic violence, we randomly sampled New York Times front-page photographs from 1976 to 1996. Our unit of analysis was the photo-caption item composed of the photographic image and its caption. Captions, which usually describe the identities and circumstances of the persons depicted and the location or type of event photographed, are traditionally treated as part of the news photograph form. Given available resources, we chose a multistage design as an efficient way of collecting an unbiased sample. Randomly selecting 1 year in every 2, we chose 11 years from the 21-year period under study. Six 2-week segments were randomly sampled from each of these 11 years.

Twenty percent $(n=202)$ of our data sample of front pages were selected randomly and coded by an author and an independent coder blind to the research hypothesis. The sample for intercoder reliability contained 678 photo-caption items. One or both coders identified violence in $22.6 \%(n=153)$ of the photos; there was agreement for .90 cases.

Coding was based on the presence or absence of violence, not the number of violent agents or incidents within a single item. ${ }^{1}$ Each violent item was coded in turn for explicit, latent, or dramatic modality. When more than one mode of violence appeared in the same photo-caption item, we confined our sample to human agents and man-made agencies of violence and excluded violence enacted by natural disasters or animals. Neither did we include accidents unless these were identified as acts of sabotage. Intercoder reliability for identifying the presence of violence and each mode of violence was .82 or greater.

We counted separately (a) items in which only U.S. agents or agencies appear, (b) items in which only non-U.S. agents or agencies appear, (c) items in which U.S. and non-U.S. agents or agencies both appear, and (d) items where group membership was indeterminate. We coded only violent agents or agencies; their targets were not coded. ${ }^{2}$ In each case, coder agreement for nationality was .95 or higher. As before, intercoder reliability was calculated using Holsti's formula (1969).

\section{Results}


Our investigation yielded a multistage random sample of 1,008 New York Times front pages containing 3,045 photo-caption items. Of these, 717 items, $23.5 \%$ of the total, were coded as violent. Latent violence appeared more than twice as often as explicit violence, and both appeared far more frequently than dramatic violence. Over half the items $(60.1 \%, n=431)$ in our sample were cases of latent violence; slightly more than one quarter $(26.9 \%, n=193)$ were cases of explicit violence; a relatively small percentage $(13.0 \%, n=93)$ were cases of dramatic violence. U.S. agents or agencies were slightly more likely than non-U.S. agents or agencies to appear in images that featured violence $(53.1 \%$ vs. $46.9 \%$, respectively). In only 19 items was the nationality of the agent or agency indeterminate or mixed (both U.S. and non-U.S.). These items were eliminated.

The findings confirmed the hypotheses. We found a strong, statistically significant association between mode of violence and group membership (U.S. or non-U.S.) of the violent agent or agency. Among cases of non-U.S. violent agents or agencies, $50.9 \%(n=171)$ depicted latent violence. Among cases of U.S. violent agents or agencies, $68.2 \%(n=260)$ depicted latent violence. Although images of U.S. violent agents or agencies depict explicit violence in $10.8 \%(n=41)$ of cases, images of non-U.S. violent agents or agencies were explicitly violent in $45.2 \%$ ( $n=$ 152 ) of cases. Among cases of non-U.S. violent agents or agencies, 3.9\% ( $n=13)$ depicted dramatic violence. Among cases of U.S. violent agents or agencies, $21.0 \%(n=80)$ depicted dramatic violence. Chi-square tests of the difference between U.S. and non-U.S. agents or agencies were significant for the overall distribution, $\chi^{2}(2, n=717)=182.2, p<.001$, as well as for each subcategory of modes of violence (latent depictions, $\chi^{2}(1, n=717)=44, p<.001$, explicit depictions, $\chi^{2}(1, n=717)=105, p<.001$, and dramatic depictions, $\chi^{2}(1, n=717)=$ $21, p<.001$ (see Table 1.)

Table 1. Percentage Distribution of Modes of Violence for Group Membership

\begin{tabular}{lll}
\hline Group membership & $\begin{array}{l}\text { Non-U.S. } \\
(n=336)\end{array}$ & $\begin{array}{l}\text { U.S. } \\
(n=381)\end{array}$ \\
\hline $\begin{array}{l}\text { Modes of violence } \\
\text { Latent }\end{array}$ & $50.9 \%$ & \\
& $(n=171)$ & $68.2 \%$ \\
Explicit & 45.2 & $(n=260)$ \\
& $(n=152)$ & 10.8 \\
Dramatic & 3.9 & $(n=41)$ \\
& $(n=13)$ & 21.0 \\
& & $(n=80)$
\end{tabular}


Our findings show that the presentation of non-U.S. agents as more explicitly violent than U.S. agents is a sturdy and reliable feature of front-page photojournalism in The New York Times. Even though there are more photographs of U.S. violence than non-U.S. violence overall, the mode of violence with which U.S. agents are associated is distinctly "softer" than that associated with non-U.S. agents. U.S. agents are more often associated with latent or dramatic forms of violence that are more subtle in their expression than the most active levels of explicit violence. By comparison, non-U.S. agents, despite their slightly smaller representation in the total sample of violent images, were associated more often with explicit violence. In fact, photographs of non-U.S. explicit violence were 3.7 times more numerous than those of U.S. explicit violence.

An additional random subsample of 194 photographs taken from our data shows that U.S. agents appear in a clear majority $(69 \%, n=134)$ of all front-page photographs, both violent and nonviolent. Among nonviolent images $(n=148)$ in this subsample, $74 \%(n=110)$ depicted U.S. agents and $26 \%(n=38)$ depicted non-U.S. agents. In other words, U.S. nonviolent agents outnumbered non-U.S. non-violent agents by nearly 3 to 1 . The U.S. thus appears comparatively nonviolent measured against other countries. U.S. agents predominate not only in images of latent and dramatic violence, as our larger sample shows, but also in images of nonviolence. Only in images of explicit violence do U.S. agents fail to predominate.

Had we applied more conventional definitions of violence to our sample (collapsing our categories of "latent" and "dramatic" violence, all or in part, into the category of "nonviolence"), our findings would still be consistent with the claim that depictions of Americans are less violent than depictions of nonAmericans. Moreover, our trimodal definition of violence is a more severe test of the spirit of our hypotheses, which together predict that non-U.S. agents are more likely to be associated with explicit violence than U.S. agents.

Beyond the pattern of quantitative differences observed in our results, there were more subtle gradations within our sample that our content analysis did not capture. We observed that images of explicit violence by non-U.S. agents displayed a drama and intensity rarely matched in images of U.S. agents. Explicitly violent non-U.S. agents were more likely to be shown beating (May 2, 1993), kicking (Oct. 12, 1993), or choking (Oct. 9, 1989). Other examples of high intensity explicit violence by non-U.S. agents included Lebanese soldiers firing rocket launchers at enemy troops in West Beirut (Feb. 7, 1984), a Japanese 
demonstrator ignited by a gasoline bomb intended for police (Mar. 27, 1978), and Israeli soldiers firing tear gas at fleeing demonstrators in Jerusalem (Apr. 13, 1982).

In striking contrast, examples of U.S. explicit violence featured federal agents comforting a wounded colleague (May 1, 1993) and police rescuing an infant injured during domestic violence (Nov. 30, 1984). Photos of U.S. explicit violence often show armed agents reestablishing order and calmness by implementing coercive authority. These images redirect attention from injury and physical restraint to repair and reassurance.

Several front-page images illustrate characteristic differences between U.S. and non-U.S. explicit violence with particular clarity. In one photograph (see Figure 1), a dozen or so uniformed South African police assume a ready-fire stance, their fingers on the triggers of their automatic weapons while other police fire tear gas at protesting Capetown University students (April 28, 1987)

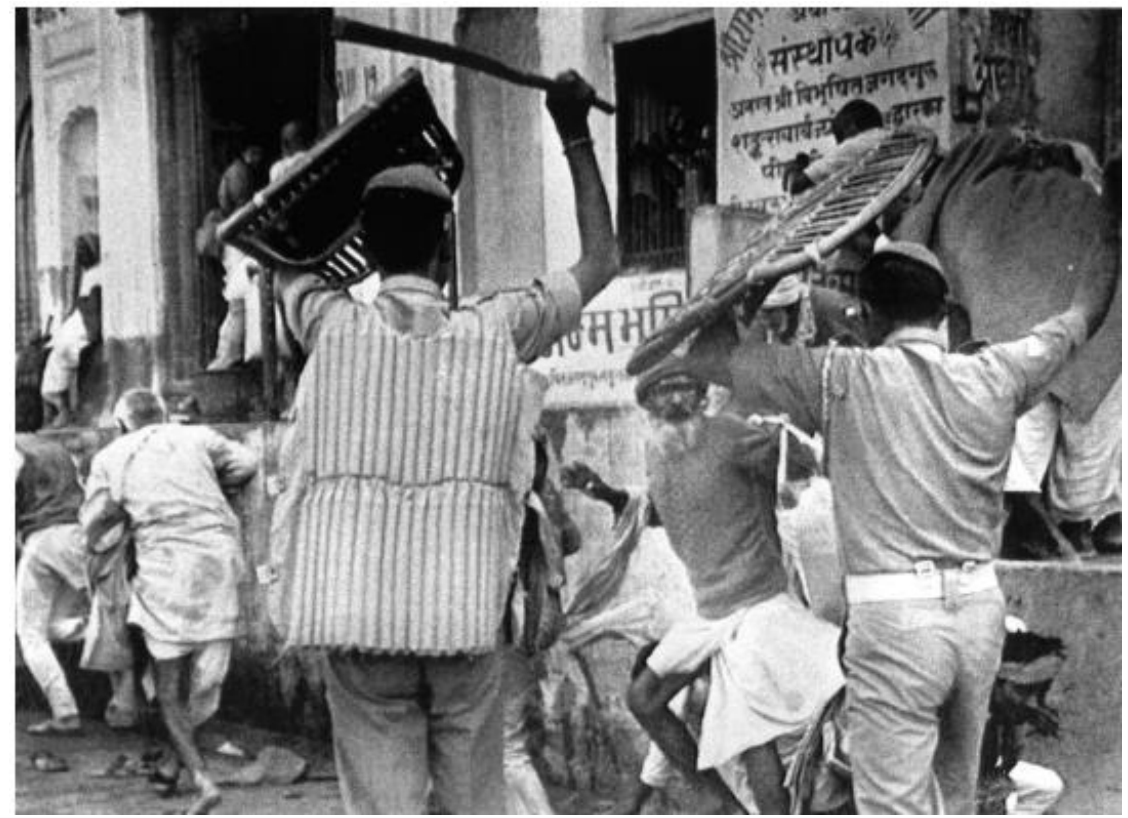

Figure 1. Non-U.S. Explicit Violence: Indian riot policemen charging Hindu militants who had stormed Ayodhya to seize a Muslim shrine (New York Times, October 31, 1990, A1). Reprinted with permission of Agence France-Presse.

Another photograph shows Indian riot police with shields and riot sticks raised in midswing, chasing citizens (Oct. 31, 1990). Both contrast with a photograph of U.S. explicit violence in which a kneeling policeman holds a large rifle in one hand and a blanket in the other, which he places over an inmate wounded in a prison riot (Feb. 4, 1980). This gesture of concern softens armed authority and the violent effects of rioting. Photos of U.S. explicit violence frequently combine opposing signifiers in this way, and they are rarely as 
uncomplicated and direct in portraying force as photos of non-U.S. explicit violence. Although U.S. explicit violence is not invisible, it is less scary than nonU.S. explicit violence. The recurring image of non-U.S. explicit violence is that of order brutally ruptured or enforced. By contrast, images of U.S. explicit violence suggest order without cruelty.

Photographs of U.S. agents engaged in latent violence likewise tend to be more benign than those depicting latent violence by non-U.S. agents. In perhaps the ultimate photograph of latent violence, a uniformed American soldier accompanying President Reagan to Moscow stands calmly beside the briefcase containing nuclear weapons codes (June 1,1988 ). Other examples of U.S. latent violence include soldiers feasting at a Christmas banquet (Dec. 26, 1990), shaving (Oct. 18, 1990), toting teddy bears (Dec. 25, 1990), and relaxing (Dec. 28, 1990), activities that fail to suggest war. Still other uniformed soldiers attend worship services with heads bent in prayer (Nov. 7, 1982; see Figure 2). Repeated representations of this kind camouflage the role of U.S. soldiers as agents of violence.

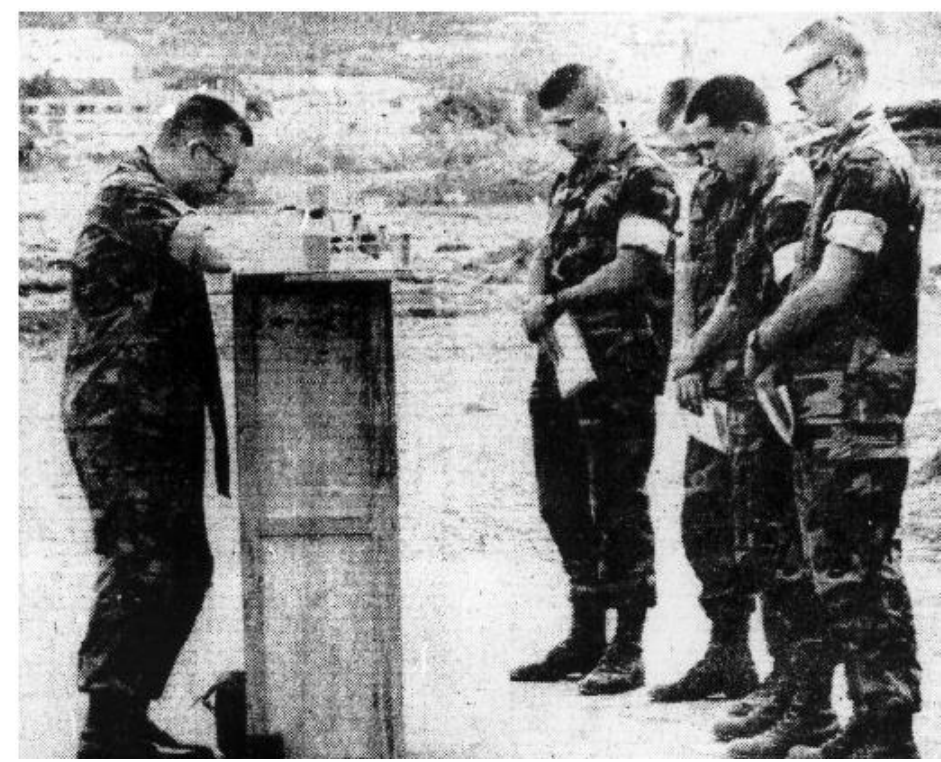

Figure 2. U.S. Latent Violence: Cmdr. John Malorana, a Navy chaplain from New Jersey, conducting services yesterday near Beirut airport (New York Times, November 7, 1982, A1). Reprinted with permission of United Press International.

Photographs of non-U.S. latent violence are less likely to appear in a context that so thoroughly disguises the relation of the agents in them to physical force. For example, a photograph of non-U.S. latent violence shows armed Iranian soldiers in a public square, weapons tensely held at the ready as they survey passersby for potential threats (Dec. 3, 1978). The caption reads, "Iranian soldiers standing guard back to back in Teheran's bazaar yesterday." By contrast, a 
photograph of U.S. latent violence depicts armed Marines holding their weapons across their chests for everyone to see while aiming at no one, mingling and conversing civilly with half a dozen Somali civilians (Jan. 10, 1993). The caption reads, "After subduing a sniper recently at a compound in Mogadishu, Marines explained the actions to residents." Though armed soldiers in both photographs protected the peace, U.S. soldiers reassured civilians with face-to-face talk while relaxing their bodies and pointing their guns away. Their violence is layered over with active interpersonal engagement and approachability. There is no ameliorating diversion in the menacing postures and poised weapons of the Iranian soldiers. Their sole focus is the community's danger to them and their danger to the community.

\section{Targeted Case Studies}

We have argued that the observed pattern of journalistic presentation of violence in The New York Times is consistent with social identity theory and critical theories positing that group codes tend to show group members in a positive light. Now we consider the possibility that our findings reflect objective circumstances more than group codes for representation. Perhaps front-page photographs feature more violence by non-U.S. agents because U.S. agents behave more peacefully, or their violence is enacted on fewer victims. To assess whether Americans are less violent than non-Americans would require a nonmediated account of violence at home and abroad that is beyond the scope of this article. There is, in any case, no shortage of serious violence in urban U.S. environments where media are plentiful and compete to attract audiences in an atmosphere in which crime is high on the national agenda. ${ }^{3}$

Perhaps the scarcity of explicitly violent images of U.S. agents indicates that Americans were not involved in military conflicts during the years sampled. In fact, U.S. military forces were on-site during a number of conflicts abroad for the dates sampled. Nevertheless, overtly violent photographs of U.S. agents in these conflicts were rarely found in our data. Front-page photographs in our sample depicted a U.S. military presence at the East and West German border, April 1977; Lebanon in January 1984; Bolivia in July 1984; the Persian Gulf throughout September, October, and December 1990; Panama in December 1990; Iraq in January 1993; Somalia in January, May, and October 1993; Haiti during October 1993 and January 1995; Kuwait for January 1993; Bosnia in January 1996; and Saudi Arabia during September and December 1990 and again in June 1996. 
As a limited exercise in comparing patterns of photojournalistic representation to "real-world" circumstances, we looked in detail at two episodes in which American military forces were involved in sustained, explicit, and politically significant violence. In contrast to the found pattern in which U.S. agents appear less explicitly violent than non-U.S. agents, we might expect a clear representation of U.S. explicit violence if objective circumstances best account for observed patterns.

The 1968 Tet offensive during the Vietnam war and the American and United Nations peacekeeping mission to Somalia to topple General Farah Aidid in 1993 provided two such episodes of concentrated U.S. explicit violence for which journalists were attentively present. (We chose not to examine the Persian Gulf War of 1991, which deployed 500,000 U.S. troops, because of severe press sanctions imposed by American military commanders.)

We coded 2 weeks of front-page photographs during two separate episodes (a total of 4 weeks) at the height of American military involvement in Somalia in 1993. The coverage intervals were June 12-25, 1993 (when U.S. and U.N. troops attacked Aidid's strongholds in Mogadishu) and Oct. 5-18, 1993 (when U.S. Rangers in search of Aidid assaulted the Olympic Hotel in a 17-hour battle). The Times published a total of 76 front-page photographs during these 4 weeks. Twenty of these contained some level of violence. Seven of these 20 concerned events in Somalia. Eight photographs depicted explicit non-U.S. violence. Six others contained non-U.S. latent violence. Despite stories reporting intensive U.S. bombardment of Somali targets, no front-page photograph depicted U.S. explicit violence in Somalia. Five photographs depicted U.S. latent violence.

We found no dearth of front-page violence during this period, only of images depicting U.S. explicit violence. This absence contrasts dramatically with graphic presentations of non-U.S. explicit violence in the same sample. One photo foregrounds a large pool of blood and three crumpled, twisted Somali corpses (June 14, 1993). The clothing of the foremost corpse is blood-drenched. The caption fixes responsibility for these deaths with Pakistani peacekeepers. A second vivid photograph of non-U.S. explicit violence shows Somalis dragging a dead American soldier through Mogadishu (Oct. 5, 1993). This photograph quickly became the defining visual emblem of U.S. military presence in Somalia. Intensive and violent U.S. military action was thus pictorially elided by a powerful image of American victimage at Somali hands. 
Despite prominent front-page stories of sustained U.S. bombing of General Aidid's headquarters, communication center, and main weapons cache, there were no front-page pictures of explicitly violent U.S. agents in this period, or U.S. gunships, or the effects of their actions on persons or property. This observation is anecdotally consistent with the pattern of our larger random sample.

We also coded all New York Times front-page photographs during the 2 weeks (Jan. 30, 1968-Feb. 12, 1968) following the launching of the Tet offensive by North Vietnamese regular Army troops against U.S. and South Vietnamese positions. Of 36 front-page photographs published in this 2-week period, 22 depicted some form of violence. Thirteen of these 22 concerned the Tet offensive. Among all violent images (not only those depicting Tet), only two depict U.S. explicit violence (just one related to Tet). Ten images portrayed U.S. latent violence. By comparison, six photos portrayed non-U.S. explicit violence. One of these was the Pulitzer Prize-winning photograph of the point-blank pistol execution of a Vietcong prisoner by a South Vietnamese general (Feb. 2, 1968). Two photos captured non-U.S. latent violence. Finally, two other photographs depicted explicit violence by agents whose group membership was indeterminate on the basis of the caption.

Because of the small sample size, none of these differences was statistically meaningful. They are striking, nonetheless. Though headline language attested to U.S. violence at home and abroad throughout the sample period (which also coincided with a New York garbage strike characterized by rioting and unrest), photographs told a different story. This was in spite of the fact that American photojournalists in Vietnam enjoyed virtually unrestricted access to a battlefield where U.S. agents were engaged in high levels of explicit violence, and the war was a volatile political issue at home.

\section{Discussion}

Is the observed pattern of violent images a deliberate choice by photo editors? We agree with the comments of Herman and Chomsky (1988):

The raw material of news must pass through successive filters. . . They fix the premises of discourse and interpretation, and the definition of what is newsworthy. . . . The operation of these filters occurs so naturally that media news people, frequently operating with complete integrity and goodwill, are able to convince themselves that they choose and interpret the news "objectively" and on the basis 
of professional news values. Within the limits of the filter constraints they often are objective; the constraints are so powerful, and are built into the system in such a fundamental way, that alternative bases of news choices are hardly imaginable. (p. 2)

Subtle distinctions among images of explicit, latent, and dramatic violence offer the kinds of filters Herman and Chomsky describe. The ideological coloring they display need not be deliberately chosen or even explicitly recognized by the editors who deploy them.

Where violence is associated with our own group, it is more likely to appear in forms that conceal its presence. By this means, our own group's capacity for violence is unceasingly displayed, but in visually indirect and even positive terms. Where violence is associated with out-groups, it is more likely to appear in forms that are cruel and disturbing.

If groups are motivated to represent themselves as less violent than other groups to which they compare themselves, what prevents groups from representing themselves exclusively in nonviolent terms? We speculate that images of violence have instructional as well as representational functions. Because society regularly uses violence to keep order and secure the survival and protection of group members at home and abroad (Marvin \& Ingle, 1999), images assist in legitimizing this institutional violence and make it palatable, just as they also mark deviance and social subordination within the national group.

Additionally, what keeps images of non-U.S. agents from appearing in explicitly violent terms even more often than our data show? We speculate that elite journalistic norms may be sensitive to the severity and frequency of explicit violent imagery in proportion to all published imagery (both in any single edition and over time). Editorial decisions to publish violent images may respond in part to norms limiting the presence of explicit violence on the front page, and not only to considerations of group identity. This possibility is beyond the scope of this article, but invites future investigation.

It would also not surprise us to discover that national newspapers in other countries champion themselves as nonviolent actors in the world even as they instruct their own citizens about violence. Here, too, further research is needed to explore the possibly distinctive ways that non-U.S. newspapers assign meanings to images of violence. Additional research is also needed to determine whether patterns of violent images found in The New York Times are found in other U.S. newspapers. Locally focused newspapers that give less coverage to international news, for example, are likely to have fewer opportunities to construct U.S. 
identity through comparisons of Americans with others. It may be that local newspapers rely more heavily than national newspapers on dimensions of race, geography, or class to make in-group and out-group distinctions below the level of nationality. (For suggestive evidence relative to race, see Entman, 1992, 1994; Gibson \& Zillman, 2000; and Oliver, 1999).

\section{Conclusion}

Because mass media reach virtually all citizens all the time, no other institution is so well positioned to disseminate messages about national identity and order. The New York Times plays a particularly influential role, assembling a moral order from the unpromising pieces of the world's disorder for an elite audience and modeling what other U.S. news media regard as authoritative and proper news practice. In this process, different forms of depicted violence help structure U.S. identity by drawing strong and reliable contrasts with outside groups. Front-page images in The New York Times effectively sanitize U.S. violence, concealing it from the inspection of citizens who might find its most graphic forms disturbing. Conversely, these representations delegitimize the violence of non-U.S. states, repeatedly rendering it in brutally explicit terms.

In the continuing debate over how best to conceptualize media violence, we offer three points for consideration. First, bright-line distinctions between violence and nonviolence should be expanded by more-line distinctions, namely, multimodal dimensions of concealment and revelation. Second, modal models of violence deepen our understanding of the social functions of media. Third, group identity plays an important but unacknowledged role in patterning violent images.

\section{References}

Alloula, M. (1987). The colonial harem. Manchester, UK: Manchester University Press.

Berkowitz, L. (1990). On the formation and regulation of anger and aggression: A cognitive neoassociationistic analysis. U.S. Psychologist, 45, 494-503.

Briggs, A. (1985). The BBC: The first fifty years. New York: Oxford University Press.

Edwards, E. (Ed.). (1992). Anthropology and photography 1860-1920. New Haven, CT: Yale University Press. 
Entman, R. M. (1992). Blacks in the news: Television, modern racism and cultural change. Journalism Quarterly, 69, 341-261.

Entman, R. M. (1994). Representation and reality in the portrayal of blacks on network television news. Journalism Quarterly, 71, 509-520.

Fishman, J. (2001). Documenting death: Photojournalism and spectacles of the morbid in the tabloid and elite newspaper. (Doctoral dissertation, University of Pennsylvania, 2001). Dissertation Abstracts International, 62, 376.

Fishman, J. (in press). Pictures of pain: Photojournalistic news norms and dialectics of distress. In L. Gross, J. S. Katz, \& J. Ruby (Eds.), Image ethics in the digital age. Minneapolis: University of Minnesota Press.

Frankel, M. (1999). The times of my life and my life with the Times. New York: Random House.

Gelsanleiter, D. (1995). Fresh ink: Behind the scenes at a major metropolitan newspaper. Denton: University of North Texas Press.

Gibson, R., \& Zillman, D. (2000). Reading between the photographs: The influence of incidental pictorial information on issue perception. Journalism \& Mass Communication Quarterly, 77, 355-366.

Glasser, T., \& Salmon, C. (1995). Public opinion and the communication of consent. New York: Guilford Press.

Hallin, D. (1994). We keep America on top of the world: Journalism and the public sphere. New York: Routledge.

Herman, E. S., \& Chomsky, N. (1988). Manufacturing consent: The political economy of the mass media. New York: Pantheon Books.

Holsti, O. R. (1969). Content analysis for the social sciences and humanities. London: AddisonWesley.

Jowett, G. S. (1993). Toward a propaganda analysis of the Gulf War. In B. S. Greenberg \& W. Gantz (Eds.), Desert storm and the mass media (pp. 74-85). Cresskill, NJ: Hampton Press.

Kirshenblatt-Gimblett, B. (1998). Destination culture: Tourism, museums, and heritage. Berkeley: University of California Press.

Lazarsfeld, P., \& Merton, R. K. (1948). Mass communication, popular taste, and organized action. In L. Bryson (Ed.), The communication of ideas (pp. 95-118). New York: Harper. 
Lutz, C. A., \& Collins, J. L. (1993). Reading National Geographic. Chicago: University of Chicago Press.

Marvin, C., \& Ingle, D. (1999). Blood sacrifice and the nation: Totem rituals and the American flag. Cambridge, UK: Cambridge University Press.

National television violence study, Vols. 1-3. (1996-1998). Thousand Oaks, CA: Sage.

Oliver, M. B. (1999). Caucasian viewers' memory of black and white criminal suspects in the news. Journal of Communication, 49, 46-60.

Quartermaine, P. (1992). Johannes Lindt: Photographer of Australia and New Guinea. In M. Gidley (Ed.), Representing others: White views of indigenous peoples (pp. 84-102). Exeter, UK: University of Exeter Press.

Reisner, A. E. (1992). The news conference: How daily newspaper editors construct the front page. Journalism Quarterly, 69, 971-986.

Tajfel, H. (1981). Human groups and social categories: Studies in social psychology. Cambridge, UK: Cambridge University Press

Tajfel, H., \& Turner, J. (1979). An integrative theory of intergroup conflict. In W. Austin \& S. Worchel (Eds.), The social psychology of intergroup relations (pp. 33-47). Monterey, CA: Brooks/Cole.

Taylor, J. (1998). Body horror: Photojournalism, catastrophe and war. Manchester, UK: Manchester University Press.

Urry, J. (1990). The tourist gaze: Leisure and travel in contemporary societies. London: Sage.

Walsh, J. (Ed.). (1995). The Gulf war did not happen: Politics, culture, warfare, post-Vietnam. Brookfield, VT: Ashgate.

Wombell, P. (1986). Face to face with themselves. In P. H. Holland, J. Spence, \& S. Watney (Eds.), Photography/Politics: Two (pp. 74-81). London: Comedia

Jessica M. Fishman (PhD, University of Pennsylvania) is a postdoctoral fellow and Carolyn Marvin (PhD, University of Illinois) is the Frances Yates professor at the Annenberg School, University of Pennsylvania. The authors thank the Annenberg School for funds to support this research. They also thank Robert Hornik for his helpful suggestions and Stacy Davis and Greg Bisson for critical assistance. An early version of this article was presented by the first author at the 1998 annual conference of the National Communication Association in New York 
${ }^{1}$ When explicit and latent violence appeared in the same image, we coded the item as explicitly violent. There were few such instances.

${ }^{2}$ Although the target of violence was frequently the same nationality as the violent agent, the question of the systematic identity of victims was beyond the scope of the present study

${ }^{3}$ We note in passing that other institutions in American society besides the press may collude in preventing pictures of explicit American violence from reaching a public audience. Within the U.S., for example, the justice system forbids photographs of state and federal executions 